\title{
Seamount benthic macrofauna off southern Tasmania: community structure and impacts of trawling
}

\author{
J. A. Koslow ${ }^{1, *}$, K. Gowlett-Holmes ${ }^{1}$, J. K. Lowry ${ }^{2}$, T. O'Hara ${ }^{3}$, G. C. B. Poore ${ }^{3}$, \\ A. Williams ${ }^{1}$
}

\author{
${ }^{1}$ CSIRO Marine Research, GPO Box 1538, Hobart, Tasmania 7001, Australia \\ ${ }^{2}$ Australian Museum, PO Box A285, Sydney South, New South Wales 2000, Australia \\ ${ }^{3}$ Museum Victoria, 71 Victoria Crescent, Abbotsford, Victoria 3067, Australia
}

\begin{abstract}
The benthic macrofauna of a group of small seamounts south of Tasmania was surveyed with a dredge and camera to assess the impact of trawling for orange roughy (Hoplostethus atlanticus; Trachichthyidae) and the efficacy of a proposed marine reserve. The seamounts were generally 300 to $600 \mathrm{~m}$ high and the peaks ranged from 660 to $1700 \mathrm{~m}$ depth. The fauna was diverse: $262 \mathrm{spe}-$ cies of invertebrates and 37 species of fishes were enumerated, compared with 598 species of invertebrates previously reported from seamounts worldwide. On seamounts that peaked at depths $<1400 \mathrm{~m}$ and that had not been heavily fished, the invertebrate fauna was dense, diverse and dominated by suspension feeders, including a matrix-forming colonial hard coral (Solenosmilia variabilis) and a variety of hard and soft (gorgonian and antipatharian) corals, hydroids, sponges and suspension-feeding ophiuroids and sea stars. Of the invertebrate species, 24 to $43 \%$ were new to science, and between 16 and $33 \%$ appeared to be restricted to the seamount environment. Trawl operations effectively removed the reef aggregate from the most heavily fished seamounts. The benthic biomass of samples from unfished seamounts was $106 \%$ greater than from heavily fished seamounts and the number of species per sample was $46 \%$ greater. Living $S$. variabilis was not found on seamounts peaking at depths $>1400 \mathrm{~m}$. These seamounts were dominated by sea urchins and had lower biomass and fewer species per sample. However, few species were restricted to either the shallowest or deepest depths sampled. The fauna unique to the region's seamounts appears to be adequately represented within a recently established 'Marine Protected Area' that encloses 12 seamounts that peak at depths $>1150 \mathrm{~m}$.
\end{abstract}

KEY WORDS: Seamount · Benthos · Impacts of trawling $\cdot$ Community structure Resale or republication not permitted without written consent of the publisher

\section{INTRODUCTION}

Although concerns about the direct and indirect impacts of trawling on seafloor habitats and demersal fish communities can be traced back to the 14th century (de Groot 1984), trawling effort and its impacts have expanded enormously over the past hundred years. A rapidly growing literature has shown that trawling may substantially alter marine benthic habitats and communities (Bradstock \& Gordon 1983, de

\footnotetext{
*E-mail: tony.koslow@marine.csiro.au
}

Groot 1984, Sainsbury 1988, Hutchings 1990, Jones 1992, Dayton et al. 1995, Auster et al. 1996, Collie et al. 1997). Several studies have also demonstrated significant secondary, or indirect, impacts on elements of the community, such as juvenile or adult fishes, that utilize biogenic structures on the seafloor directly impacted by trawling (Bradstock \& Gordon 1983, Sainsbury 1988). These latter studies both led to areal closures to trawling.

Trawl fishing has not only intensified, it has also expanded into a range of hard rocky and reefal environments not previously accessible to this gear, based on the development of strong synthetic net fibres, 
rockhopper gear-large rubber bobbins and metal discs along the footrope-and precise electronic positioning systems both for the vessel and to monitor net performance. Seamounts are one such environment to become subject to intensive trawl fishing in recent decades.

Seamounts provide a unique deep-sea environment due to the topographically-enhanced currents in their vicinity (Roden 1986). In the water column, substantial aggregations of deep-bodied fishes, such as the pelagic armourhead (Pseudopentaceros wheeleri), Sebastes spp., orange roughy (Hoplostethus atlanticus) and oreosomatids are commonly found around seamounts (Boehlert \& Sasaki 1988, Koslow 1996, 1997, Koslow et al. 2000). These aggregations are supported in the otherwise food-poor deep sea by the enhanced flux of prey organisms past the seamounts and the interception and trapping of vertical migrators by the uplifted topography (Tseitlin 1985, Genin et al. 1988, Koslow 1997). Discovery of these aggregations led to seamounts being increasingly targeted by trawlers throughout the world's oceans: i.e. the massive but short-lived fishery for pelagic armourhead in the North Pacific in the 1960s and the development of orange roughy and oreosomatid fisheries in the waters around New Zealand and southeastern Australia in the 1980s and subsequently in the North Atlantic and elsewhere (Clark 1999, Koslow et al. 2000).

The seamount benthic environment is also distinct from that found on the surrounding seafloor, and may be particularly susceptible and sensitive to disturbance by trawling. Due to the enhanced currents, the benthic communities around seamounts are typically dominated by corals and other suspension feeders (Genin et al. 1986, Wilson \& Kaufmann 1987, Rogers 1994), rather than the deposit feeders typical of most of the deep-sea benthos. Although seamount benthic communities were first sampled by the 'Challenger' expedition (1872 to 1876 ), the diversity and exceptionally localized distribution of species from these unique deep-sea communities has only recently been recognized (Richer de Forges et al. 2000). The biology and life history of virtually all seamount benthic species remain very poorly known, but some species appear to be extremely long-lived (on the order of 70 to hundreds of years: Vacelet et al. 1992, Grigg 1993, Richer de Forges 1998). A bycatch of coral and other invertebrates characteristic of seamount benthic communities is reported from the New Zealand orange roughy trawl fishery (Probert et al. 1997), but overall community impacts are not known.

Since 1989, orange roughy and the oreosomatids Pseudocyttus maculatus and Allocyttus niger have been fished from a field of approximately 70 small seamounts (300 to $600 \mathrm{~m}$ high and several kilometres across at the base) at depths of between 1000 and $2000 \mathrm{~m}$ on the continental slope south of Tasmania, Australia (Hill et al. 1997). From 1988 to 1996 (the last year for which data are available), 21536 non-zero catch trawls were reported from the south Tasmanian seamounts (Australian Fisheries Management Authority unpubl. data).

Commercial orange roughy trawls operate on the bottom and have heavy bobbins along the foot rope, so epibenthic organisms are removed or damaged along the track of normal trawl operations. There are no quantitative data on coral bycatch, but J.A.K. and K.G.H. have observed tonnes of coralline material brought to the surface in a single trawl haul when a new area was fished. During the peak period of the orange roughy fishery, there was interest in developing a precious coral industry based on the bycatch of bamboo (Gorgonacea: Isididae), gold (Gorgonacea: Primnoidae) and black (Antipatharia: Antipathidae) corals (Grigg \& Brown 1991).

In 1994, the Australian Geological Survey Organization (AGSO) used broad-swath acoustic techniques to map the seabed from 300 to $4500 \mathrm{~m}$ depth off southern and western Tasmania, identifying the precise location and heights of all seamounts (AGSO 1995). The ready availability of these maps led to concern for the future of the seamount benthic fauna if these features were all fished. A report commissioned by Environment Australia noted that the Tasmanian seamount fauna had not been scientifically studied, but the fauna in these habitats was typically diverse, contained a large endemic component, differed from that on the surrounding seafloor, and had extremely limited regenerative capacity (Koslow 1994). The report recommended that a substantial area of the newly mapped seamounts be set aside as an interim conservation measure and that the diversity and distribution of the seamount benthic fauna be assessed to provide information to aid in their conservation and management. In 1995, an interim protected area was declared in which the fishing industry agreed not to trawl for a $3 \mathrm{yr}$ period to allow time for the research to be carried out and longer term management measures to be put in place (see Fig. 1).

Most previous studies of the seamount fauna have focused on particular taxa (see Wilson \& Kaufmann 1987 and Rogers 1994 for recent reviews). Although our study is not exhaustive, we enlisted the support of 22 taxonomists in addition to ourselves to identify major components of the benthic macro- and megafauna (see 'Acknowledgements'). The present study examines the influence of depth, as well as the impact of trawling, on the composition of the benthic macrofauna on seamounts south of Tasmania. 
Table 1. Fishing effort and dredge sample sites. (R) indicates site is within the protected area; T: top; S: slope; B: base. Fishing effort is in number of non-zero catch trawls recorded in the Australian Fisheries Management Authority database between 1988 and 1996

\begin{tabular}{|c|c|c|c|c|}
\hline Seamount & Habitats sampled & $\begin{array}{l}\text { Depth of peak } \\
(\mathrm{m})\end{array}$ & $\begin{array}{l}\text { Fishing effort } \\
\text { (no. trawls) }\end{array}$ & Position \\
\hline Andy's & $\mathrm{T}, \mathrm{S}, \mathrm{B}$ & 660 & 419 & $44^{\circ} 11.6^{\prime} \mathrm{S}, 146^{\circ} 58.9^{\prime} \mathrm{E}$ \\
\hline Macca's & $\mathrm{T}, \mathrm{S}, \mathrm{B}$ & 670 & 968 & $44^{\circ} 11.8^{\prime} \mathrm{S}, 147^{\circ} 02.5^{\prime} \mathrm{E}$ \\
\hline Main Pedra & $\mathrm{T}, \mathrm{B}$ & 714 & 3069 & $44^{\circ} 15.5^{\prime} \mathrm{S}, 147^{\circ} 05.8^{\prime} \mathrm{E}$ \\
\hline Sister 1 & $\mathrm{~T}, \mathrm{~S}, \mathrm{~B}$ & 915 & 693 & $44^{\circ} 16.7^{\prime} \mathrm{S}, 147^{\circ} 15.6^{\prime} \mathrm{E}$ \\
\hline Dory Hill & $\mathrm{T}, \mathrm{S}, \mathrm{B}$ & 1090 & 1 & $44^{\circ} 19.6^{\prime} \mathrm{S}, 147^{\circ} 07.2^{\prime} \mathrm{E}$ \\
\hline Hill U (R) & $\mathrm{T}, \mathrm{S}$ & 1155 & 0 & $44^{\circ} 19.5^{\prime} \mathrm{S}, 147^{\circ} 10.8^{\prime} \mathrm{E}$ \\
\hline Hill 38 & $\mathrm{~T}, \mathrm{~S} / \mathrm{B}$ & 1195 & 5 & $44^{\circ} 12.9^{\prime} \mathrm{S}, 147^{\circ} 21.4^{\prime} \mathrm{E}$ \\
\hline Hill J1 & $\mathrm{T}, \mathrm{S}, \mathrm{B}$ & 1235 & 42 & $44^{\circ} 15.4^{\prime} \mathrm{S}, 147^{\circ} 20.9^{\prime} \mathrm{E}$ \\
\hline Hill A1 (R) & $\mathrm{T}, \mathrm{S}$ & 1300 & 0 & $44^{\circ} 19.7^{\prime} \mathrm{S}, 147^{\circ} 16.4^{\prime} \mathrm{E}$ \\
\hline Hill B1 (R) & $\mathrm{T}, \mathrm{S}, \mathrm{B}$ & 1300 & 16 & $44^{\circ} 18.5^{\prime} \mathrm{S}, 147^{\circ} 16.8^{\prime} \mathrm{E}$ \\
\hline Hill K1 (R) & $\mathrm{T}, \mathrm{B}$ & 1314 & 2 & $44^{\circ} 17.6^{\prime} \mathrm{S}, 147^{\circ} 23.2^{\prime} \mathrm{E}$ \\
\hline Hill V & $\mathrm{T}, \mathrm{S}, \mathrm{B}$ & 1400 & 0 & $44^{\circ} 23.6^{\prime} \mathrm{S}, 147^{\circ} 10.7^{\prime} \mathrm{E}$ \\
\hline Hill D1 (R) & $\mathrm{T}, \mathrm{B}$ & 1580 & 0 & $44^{\circ} 23.2^{\prime} \mathrm{S}, 147^{\circ} 18.8^{\prime} \mathrm{E}$ \\
\hline Hill W (R) & $\mathrm{T}$ & 1700 & 0 & $44^{\circ} 26.1^{\prime} \mathrm{S}, 147^{\circ} 13.7^{\prime} \mathrm{E}$ \\
\hline
\end{tabular}

\section{METHODS}

The survey was carried out on the FRV 'Southern Surveyor' from 20 January to 1 February 1997. Seamounts were selected to cover as wide a range of depths and fishing effort as possible in the seamount field south of Tasmania (Table 1). Andy's and Macca's are among the shallowest seamounts in the area, and Hills D1 and W among the deepest; the base of these seamounts at $\sim 2000 \mathrm{~m}$ is also at the limit of the research vessel's dredging capability. Macca's, Main Pedra and Sister are among the most heavily fished seamounts, and fishing effort varied among seamounts by several orders of magnitude.

Fishing effort was assessed from fishermen's logbook records. Maintenance of the logbook is a license condition, and trawl effort data are believed to be reasonably accurate, because fishing vessels are required to have a satellite-based vessel-monitoring system so that their position may be monitored by the regulatory agency. All non-zero catch trawls were summed for the period 1988 to 1996 within rectangles of dimensions of 2 ' latitude $\times 2$ ' longitude $(3.7 \times 2.7 \mathrm{~km})$ centred on each of the sampled seamounts. The fishing logbook data are downwardly biased, since no entry is recorded when a trawl is unsuccessful and lands no fish.

Trawls on the seamounts are typically on the bottom for 1 to $10 \mathrm{~min}$. Given a mean tow speed of $6 \mathrm{~m} \mathrm{~s}^{-1}$ and wingspread of $20 \mathrm{~m}$, a tow impacts an area of $\sim 7200$ to $72000 \mathrm{~m}^{2}$. A typical seamount in this region is on the order of $400 \mathrm{~m}$ in height and 1.0 to $1.5 \mathrm{~km}$ in radius at its base, for a surface area of $23.4 \times 10^{6}$ to $7.3 \times 10^{6} \mathrm{~m}^{2}$. A tow therefore impacts between approximately 0.1 and $2 \%$ of the area of a seamount. A logarithmic scale was used to characterize broad categories of fishing effort, i.e. very heavily fished (>1000 trawls), heavily fished (100 to 1000 trawls), lightly fished (10 to 100 trawls), and very lightly fished (1 to 10 trawls). The heavily and very heavily fished seamounts all peak at depths $<1000 \mathrm{~m}$ and would be expected to be heavily impacted. Fishing effort ranged from unfished to lightly fished on the deeper seamounts, regardless of whether they are within the protected area; most had $\leq 10$ tows and would be expected to be little impacted by fishing.

Because the seamount benthic habitat in the area had not been previously studied, the composition of the pre-fishery biological community can only be inferred from the composition on unfished hills, and the impact of the fishery can only be inferred by comparing heavily and unfished hills. Because the fishery is concentrated on seamounts at shallower depths, the effects of depth and fishing are confounded: all shallow hills surveyed were moderately to heavily fished and all deeper hills were unfished or very little fished (Table 1).

Four seamounts covering a range of depths (peaks from 714 to $1580 \mathrm{~m}$ depth) and fishing effort ( 0 to $>3000$ trawls) were surveyed photographically (Tables $1 \& 2$ ). Two or 3 photographic transects were carried out on each of these seamounts from the pinnacle to the base. The first 2 transects were oriented orthogonally in east-west and north-south directions. On 2 of the seamounts where a third transect was carried out, it approximately replicated a previous transect. Mean transect length was $2652 \mathrm{~m}$ (range: 2213 to $3310 \mathrm{~m}$ ). Depths and the positions of the seamounts were from the broad-swath mapping chart (AGSO 1995) and GPS position fixes aboard the FRV 'Southern Surveyor', which is accurate to within $\sim 100 \mathrm{~m}$. 
Table 2. Seamounts surveyed photographically. Depth refers to $\mathrm{m}$ below the sea surface of the photographic transects. $(\mathrm{R})$ indicates site is within the protected area

\begin{tabular}{|lcr|}
\hline Seamount & No. transects & Depth range (m) \\
\hline Main Pedra & 3 & $714-1320$ \\
Sister 1 & 2 & $915-1520$ \\
K1 (R) & 3 & $1314-1799$ \\
D1 (R) & 2 & $1580-2180$ \\
\hline
\end{tabular}

A Photosea 2000 deepwater camera and 2 strobes were activated from the surface. An acoustic pinger ascertained height above bottom, and photos were generally taken with the camera between 1 and $4 \mathrm{~m}$ off bottom, with the camera facing down. The mean number of photos per transect was 106 (range: 67 to 150). The mean distance between photos on a transect (estimated from the total number of photos divided by the transect length) was $27 \mathrm{~m}$ (range: 16 to $38 \mathrm{~m}$ ). Photographs were taken while the vessel drifted over the seamounts. Drift speed averaged $50 \mathrm{~cm} \mathrm{~s}^{-1}$. The precise position of the camera was not known but was estimated relative to that of the vessel, based on the lag

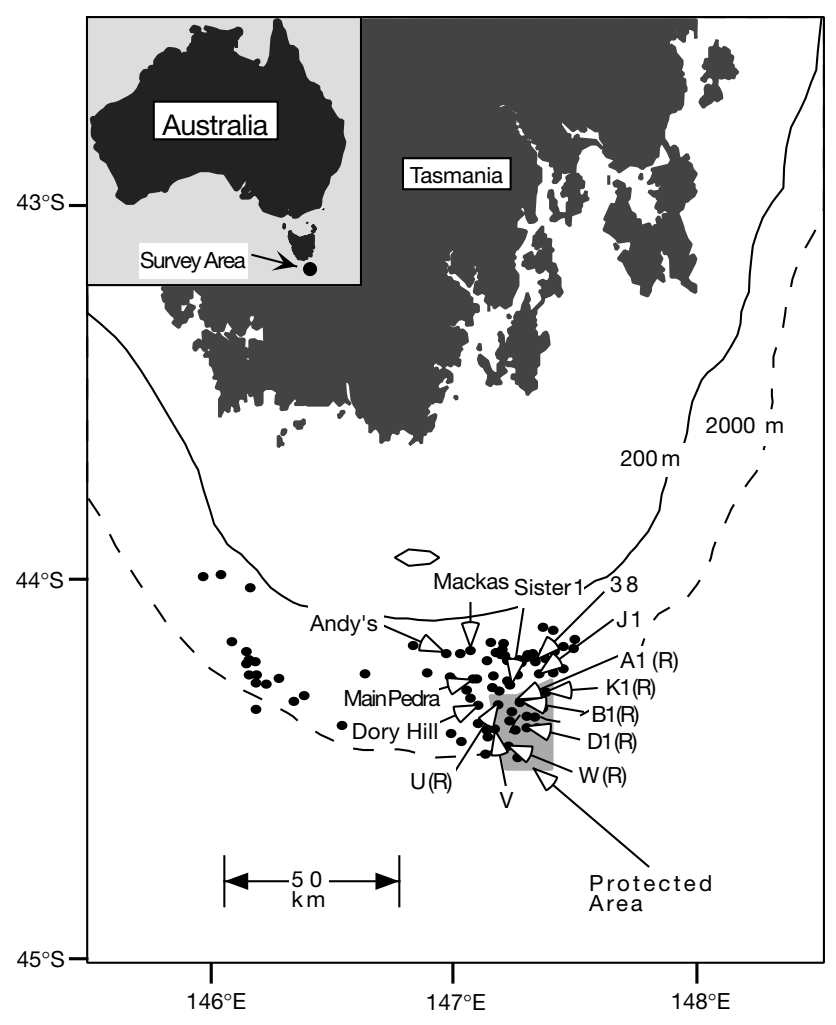

Fig. 1. Map showing position of seamounts surveyed and other seamounts in the area and location of the 'Marine Protection Area'. (R) indicates seamount is within the protection area time between the vessel and camera arriving at the peak and base of each seamount.

The photographs were assessed for percent cover by bottom type (i.e. living and dead coral aggregate, coral rubble, coral sand, mud/silt, rock, and barnacle plates) and for the numbers of each type of non-colonial organism. For data analysis, photographic frames were grouped by $\sim 100 \mathrm{~m}$ depth intervals on each seamount.

We sampled the benthic fauna with a Lewis (1999) dredge with a mouth area of $0.72 \mathrm{~m}^{2}(1.2 \mathrm{~m}$ wide $\times$ $0.6 \mathrm{~m}$ high) and a stretched maximum mesh width of $25 \mathrm{~mm}$ in the cod end. Collections were thus limited to the macro- and megafauna. The dredge was towed from a $25 \mathrm{~mm}$ trawl wire at 3 knots for $\sim 5$ to $10 \mathrm{~min}$ on bottom; height above bottom was monitored continuously with a Furuno net sonde mounted on the dredge.

Seamounts with peaks from 660 to $1700 \mathrm{~m}$ below the surface were sampled with the dredge. We attempted to sample the summit, slope and base of each seamount. However, the precise position of samples, particularly on the deeper seamounts, was uncertain, given their depth, small basal diameter (typically $2 \mathrm{~km}$ ), the potentially strong but unknown currents in the vicinity, and the lack of positioning equipment on the gear itself. Full sampling did not always prove possible, particularly on some of the deepest seamounts, due to the rugged nature of the environment. One sample (from Hill 38) extended across both the slope and base habitats. In all, there were 34 successful dredge samples obtained from 14 seamounts, 6 of which were in the protected area (Fig. 1, Table 1).

The dredge samples were sorted at sea into major taxonomic groups (e.g. sponges, crinoids, sea stars, colonial corals, solitary corals, black corals, gold corals, hydroids), weighed by group and preserved. Specimens from as many species as could be recognized in the field were photographed prior to preservation. Principal responsibility for taxonomic identification was allocated among the authors as follows: Lowry, amphipods and other scavenging crustaceans; O'Hara, ophiuroids; Poore, decapods; but we were assisted by others in Australia, New Zealand, France and the USA (see 'Acknowledgements'). The individual species' weights per sample were subsequently estimated pro-rata based on the laboratory-based identification and enumeration of the species in each sample and the shipboard weights of major taxonomic groups. Most major groups sampled by the gear were identified to species. (See Koslow \& Gowlett-Holmes [1998] for a full list of species identified.)

To examine patterns in community structure in the dredge data, we calculated the Bray-Curtis index of distance between samples and species, based on both untransformed weights and presence-absence data (Legendre \& Legendre 1983). Species with <3 occur- 
rences and a station with only 1 species were removed before analysis. Both the (invertebrate species $\times$ sample) data matrix and its inverse were analysed ( $Q$ and R analyses: Legendre \& Legendre 1983, p. 172) using standard hierarchical clustering based on the unweighted pair-group method using arithmetic averages. We also analysed the data using the completelinkage method of clustering and ordination analysis based on non-metric dimensional scaling to check the robustness of the cluster results (Legendre \& Legendre 1983). Analyses were carried out using the SPSS statistical package (Norusis 1994).

Droplines and traps were deployed for 2 to $7 \mathrm{~h}$ at 4 seamounts to sample the motile fauna (fishes, crustaceans, etc.) living in association with the benthic environment. Three trap-types were deployed: fish traps (overall: $86 \times 85 \times 120 \mathrm{~cm}, 18 \mathrm{~mm}$ square mesh, 2 openings, mouth area $\sim 500 \mathrm{~cm}^{2}$ ), crab pots (overall: $70 \times 88 \times 30 \mathrm{~cm} ; 20 \times 40 \mathrm{~mm}$ mesh; 2 openings, mouth area $\left.289 \mathrm{~cm}^{2}\right)$ and small tapered prawn traps $(35 \mathrm{~cm}$ length $\times 10 \mathrm{~cm}$ diam. at mouth opening, mesh $0.5 \mathrm{~cm}$ diam.) to sample small scavengers such as amphipods. Cut or minced jack mackerel was used as bait in the traps and squid as bait for the drop-line hooks. About 100 hooks/dropline were deployed, and the lines were set so the first hook was $2 \mathrm{~m}$ above bottom, with subsequent hooks at $1 \mathrm{~m}$ intervals. Two hook sizes were used on each line: \#6 and \#4 kirbed Milward hooks, the sizes used by commercial long-line fishers for flathead (Platycephalus spp.) ( 500 g) and trevalla (Hyperoglyphe antarctica) ( 5 kg), respectively.

\section{RESULTS}

\section{Photographic survey}

Of the 4 seamounts surveyed photographically, intact coral cover, living or dead, was only found on the unfished/very lightly fished seamounts, D1 and K1, within the reserve (Fig. 2). Live coral cover was observed only along the slope of the shallower (K1) of the 2 unfished seamounts, but even there the proportion of dead coral aggregate far outweighed the proportion of living coral (Fig. 2). The lack of living coral observed on the deeper unfished seamount (D1) is consistent with the general lack of living coral recovered from dredge sampling of seamounts peaking at depths $>1400 \mathrm{~m}$ (see below). The cause of the high proportion of dead coral aggregate, even on unfished seamounts, is not known, but could be due to predation, disease, or long-term environmental variability, leading to poorer conditions for growth of this coral on deeper seamounts, at least at this time. The age of dead portions of the reef is not known, but presumably this dense calcareous material would withstand dissolution and bio-erosion for substantial periods of time.

Both living and dead aggregates of the dominant coral (Solenosmilia variabilis) were most abundant at mid-depths along the slopes of Seamounts K1 and D1 (Fig. 2). Maximal cover by combined living and dead coral aggregate was $27 \%$ at $1800 \mathrm{~m}$ on D1, the deeper seamount, and $63 \%$ at $1500 \mathrm{~m}$ on K1. Cover by coral aggregate decreased to $\leq 10 \%$ both toward the summit and base of the seamounts.

On Seamount K1, the proportion of the bottom covered by mud was minimal at mid-depths and greatest near the base or summit, the inverse of the pattern of bottom cover by the coral aggregate. On the deeper seamount, D1, bottom cover by mud increased monotonically with depth.

The substrate of the heavily fished seamounts, Pedra and Sister 1, differed markedly from those in the protected area. The substrate of Pedra (the most heavily fished seamount in the area) was predominantly bare rock ( $>90 \%$ at most depths). Coral material on these 2 seamounts was either rubble or sand (i.e. coral aggregate that had been broken up more or less finely). Fishers report that there was a large coral bycatch in the early years of the fishery (J. A. Koslow pers. comm.). The pre-fishery coral cover on these shallower seamounts cannot be ascertained, but the data suggest that virtually all coral aggregate, living or dead, was removed by the fishery, leaving behind bare rock and pulverized coral rubble. The high proportion of coral rubble and sand at 1200 to $1300 \mathrm{~m}$ on Sister 1, the lower limit of orange roughy trawling, suggests that trawling worked this material down the slope, following the direction of trawling.

Further photographic evidence of the impact of fishing included the presence in a photo from Sister 1 of the broken base of a large bamboo coral lying on the bare rock substrate, and several photos showing trawl tracks from the otter boards on the bare rock (Fig. 3).

\section{Faunal collections}

Thirty-seven fish species were collected by longline, trap and sled (for species list, see Appendix B of Koslow \& Gowlett-Holmes 1998). Although longline and trap catches accounted for most of the large fishes taken, relatively few species (8) were caught by these 2 methods, and they were wide-ranging species typical of the continental slope. Squalid sharks comprised the majority of longline catches, with Etmopterus granulosus and Etmopterus sp. B dominant. The eels Diastobranchus capensis and Simenchelys parasiticus (Synaphobranchidae) were the dominant fishes in trap catches. 

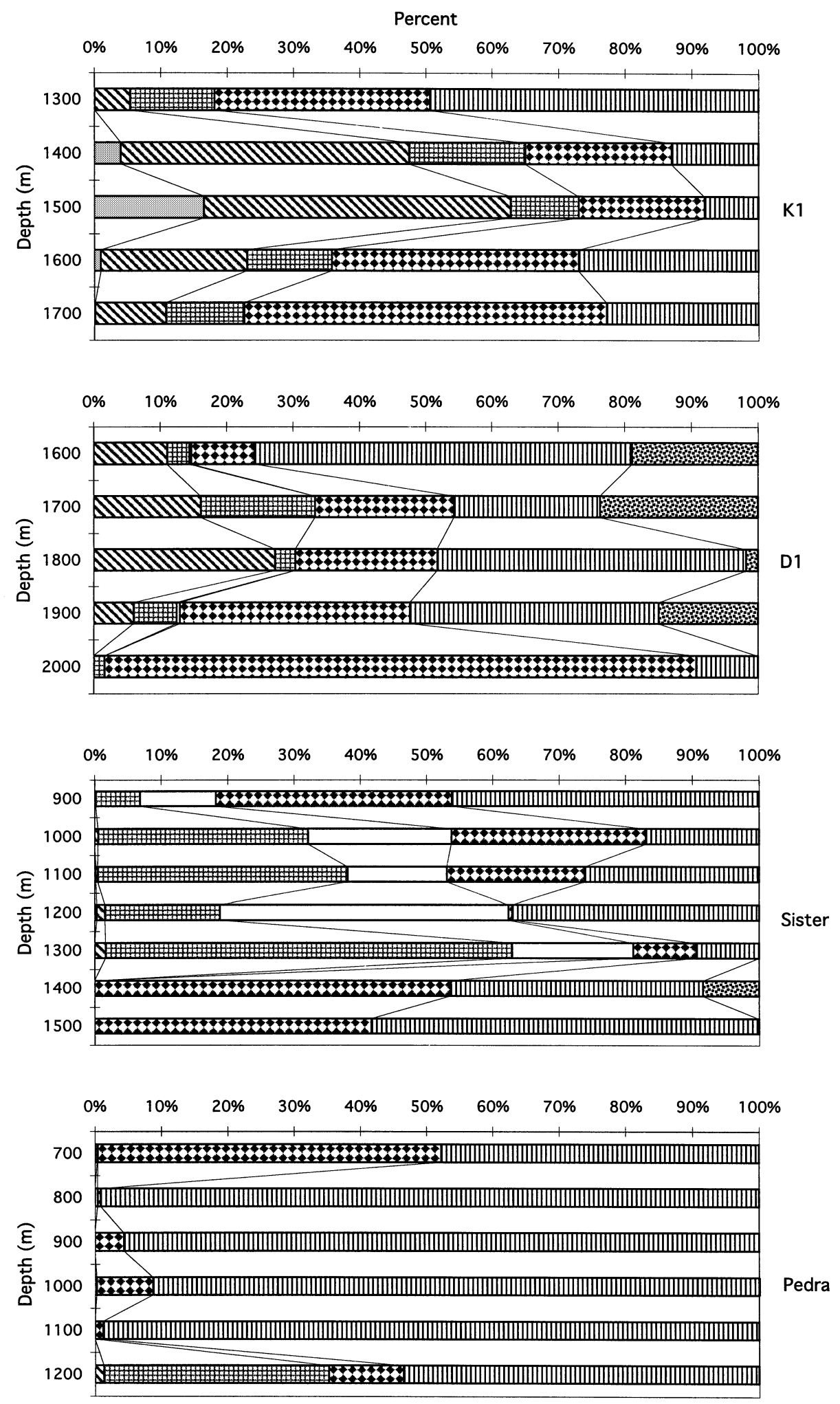

$\square$ Live coral $\mathbf{Q}$ Dead coral aggregate $⿴$ Coral Rubble $\square$ Coral Sand $\mathbf{\square}$ Mud mRock G Barnacle Plates

Fig. 2. Percent cover of the seamount seafloor by substrate type based on photographic transects over 4 seamounts. Hills K1 and D1 are within the protected area; Hills Sister and Pedra are heavily fished. The upper $100 \mathrm{~m}$ represents the summit of each seamount; the lowest 200 to $300 \mathrm{~m}$ is from the base of the seamount, and intervening depths are along the seamount slope 
Fishes were uncommon in the dredge samples, because of its small mouth opening. Nonetheless, the species distribution of the dredge collection was highly even (24 species from a total of 63 specimens), and contained a high proportion of species comprising new Australian records or undescribed species. Excluding wide-ranging continental slope species (those caught by trap and longline) and mesopelagic species probably caught during the descent and ascent of the sled (from the families Bathylagidae, Phosichthyidae, Sternoptychidae and Myctophidae), $60 \%$ of near-bottom species caught in the dredge (15 of 25) had not been previously recorded in the Australian ichthyofauna (Paxton et al. 1989) or were undescribed species. This indicates a specialized fauna restricted to the seamounts, probably containing many endemic species, since the demersal fish fauna of the continental slope around Tasmania, exclusive of the seamounts,
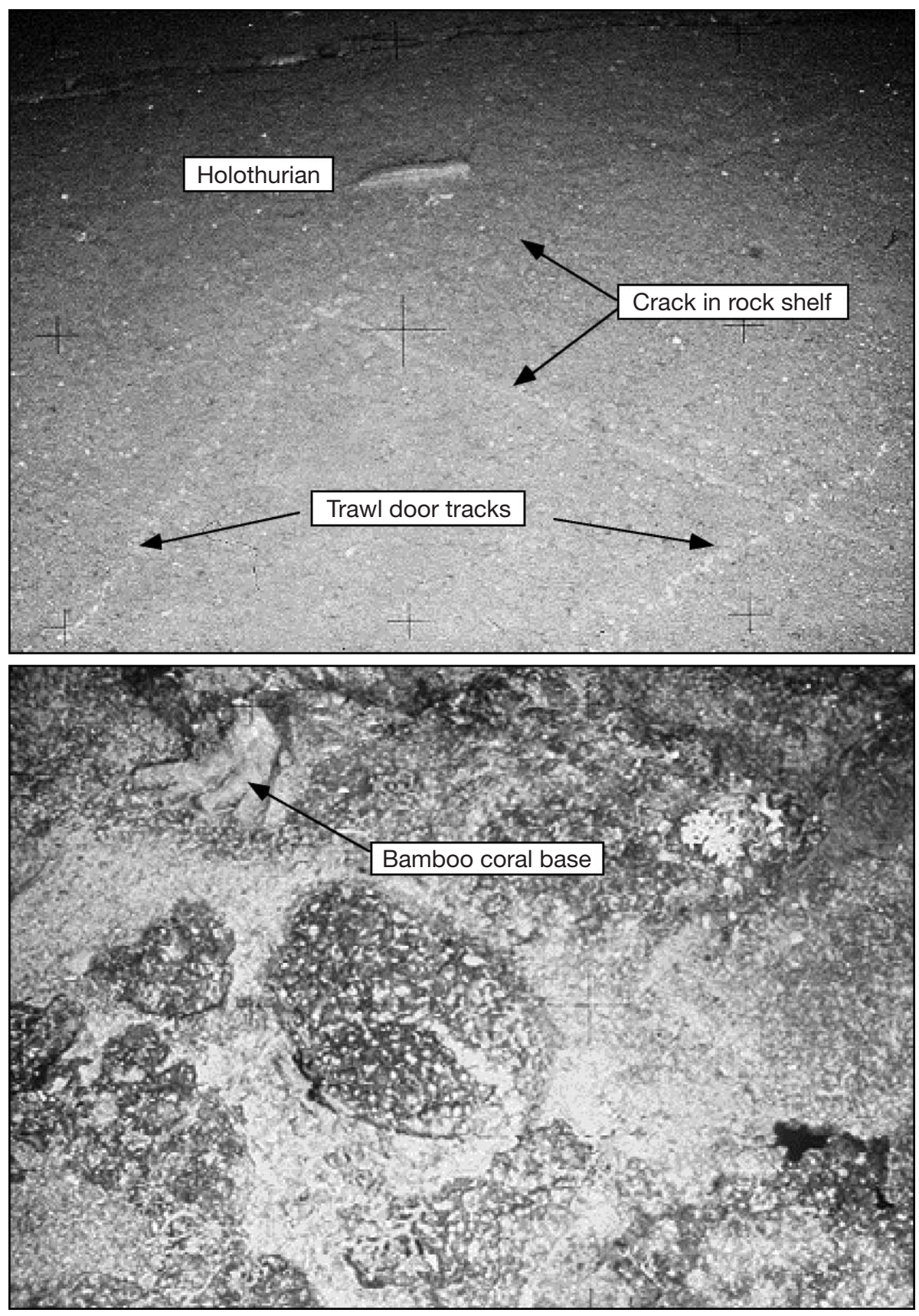

Fig. 3. Photographs from heavily fished seamounts showing (upper) trawl tracks on bare rock substrate on Main Pedra seamount, and (lower) broken base of a bamboo coral from Sister 1 seamount 
was extensively surveyed at these depths in 1988 to 1989 (Koslow et al. 1994). Three groups in particular appear largely restricted to the seamount habitat: Cataetyx spp. (Bythitidae) and Paralaemonema spp. (Moridae), each represented by several undescribed species (among 30 specimens), and 2 species of Muraenolepis (Muraenolepididae) (among 5 specimens), a group restricted largely to the Antarctic/sub-Antarctic (Chiu \& Markle 1990) and known previously in Australian waters from only 2 specimens.

The fish collection was too small for rigorous statistical analysis, but the number of species appeared to diminish both on the deepest seamounts (depth of peak $\geq 1400 \mathrm{~m}$ ) and on the most heavily fished seamount (Fig. 4). The apparent decrease in species richness on very lightly fished and unfished seamounts (Fig. 4B) is likely to be an artifact, since these are generally the deepest seamounts.

No juvenile fishes of commercially exploited deepwater species, such as orange roughy (Hoplostethus atlanticus) or the oreos (Oreosomatidae), were caught, indicating that they probably do not utilize this habitat as juveniles.

Within the invertebrate groups thus far examined, 242 species have been recognized, and there are at least 20 additional species in groups yet to be examined in detail (Table 3; and Koslow \& Gowlett-Holmes 1998). Of the 242 putative species distinguished thus far, only $75(31 \%)$ have been positively identified to known species; at least 63 and possibly as many as 103 putative species (26 to $44 \%$ ) are believed to be new to science; an estimated $35 \%$ appear to be restricted to the seamount habitat; and approximately $48 \%$ are known only from this region. The range in some of these estimates reflects uncertainty in species identifications, resulting from poor understanding of the morphological variability and geographical range of deepwater species in general and the taxonomy of certain groups.

\section{Community analysis of dredge samples}

Cluster analysis based on the untransformed species-weight data from the dredge samples indicated that sample sites were comprised of 3 primary community types. The first was found at unfished to lightly fished sites $(<50$ trawls $)$ at moderate depth (peaks at $<1400 \mathrm{~m}$ depth) and was dominated by the living colonial coral, Solenosmilia variabilis (31 to $91 \%$ of sample biomass). The second was found predominantly on the deepest seamounts (peaks >1400 m depth), but also included the shallow, fished seamount, Macca's. These sites were dominated by sea urchins (25 to $95 \%$ of the biomass) (Fig. 5, Table 4). A third group of stations consisted of depauperate samples from shallow, heavily fished sites (except for a single sample from Hill A1) with little linkage among each other or with
Fig. 4. Total number of species of fishes per seamount (bars) and number per sled sample (line) in relation to the (A) peak depth of the seamounts and (B) the level of fishing effort. Unfished: 0 trawls; V light: 1-10; Light: 11-100; Heavy: 101-1000; V heavy: >1000 trawls 
other samples. Ordination analysis based on non-metric dimensional scaling indicated the same groupings of stations; the results are therefore not shown.

Mean sample biomass at coral-dominated sites was more than 3-fold higher than at sites dominated by sea urchins and 7-fold higher than at the heavily fished sites (Table 4, Kruskal-Wallis rank-sum test for differences, $\mathrm{p}<0.0001$ ). However, the biomass of urchins at the urchin-dominated sites was almost 3-fold higher than at coral-dominated sites, despite the markedly lower overall biomass at urchin-dominated sites (Table 4: MannWhitney $U$-test, $\mathrm{p}<0.01$ )

The coral-dominated sites were also more speciose, samples from them containing 46 and $106 \%$ more species than the urchin-dominated and heavily fished sites, respectively (Table 4: Kruskal-Wallis rank-sum test for differences, $\mathrm{p}<0.05)$. Many solitary corals, hydrocorals, octocorals, brachiopods, sponges, and bivalves used the coral matrix as their base of attachment, and the lattice framework provided shelter for crustaceans, ophiuroids and others, leading to the association between Solenosmilia variabilis and many of these species in Cluster 1 (Table 5). A number of species commonly occurring in this assemblage (e.g. Trichopeltarion n. sp., Munida n. sp. 1, Paguridae n. gen. n. sp.) are previously undescribed and are not known from the adjacent slope region, and thus appear to be seamount endemics.

Sites dominated by live colonial coral, Solenosmilia variabilis, included both the shallower seamounts within the protected area (peaks $<1400 \mathrm{~m})$ (A1, B1, K1 and U1) and seamounts outside the protected area that were unfished or only lightly fished ( $<50$ trawls) because they are somewhat deeper and less frequented by orange roughy (i.e. J1, Dory Hill and Hill 38).

There were no significant differences in mean sample size, species number or apparent community structure between coral-dominated seamounts in or outside the protected area (Table 6). A sample site from the base of the heavily fished seamount Sister 1 also con-

Table 3. Invertebrates in study area, by phylum and major group: numbers of species, number and proportion likely to be new to science, and biogeographic affinities. Ranges indicate those species definitely considered new (lower value) plus those possibly new (higher value)

\begin{tabular}{|c|c|c|c|c|c|c|c|c|c|c|}
\hline $\begin{array}{l}\text { Phylum/ } \\
\text { group }\end{array}$ & $\begin{array}{c}\text { No. of } \\
\text { species }\end{array}$ & $\begin{array}{c}\text { Species } \\
\text { positively } \\
\text { identified }\end{array}$ & $\begin{array}{l}\text { Species } \\
\text { new to } \\
\text { science }\end{array}$ & $\begin{array}{c}\text { Sea- } \\
\text { mount } \\
\text { endemic }\end{array}$ & $\begin{array}{c}\text { SE } \\
\text { Australia }\end{array}$ & $\begin{array}{l}\text { Trans- } \\
\text { Tasman }\end{array}$ & $\begin{array}{l}\text { Indo- } \\
\text { West } \\
\text { Pacific }\end{array}$ & $\begin{array}{l}\text { Southern } \\
\text { Ocean }\end{array}$ & $\begin{array}{c}\text { New } \\
\text { Caledonia } \\
\text { area \& ridges }\end{array}$ & $\begin{array}{l}\text { Widespread, } \\
\text { cosmopolitan }\end{array}$ \\
\hline $\begin{array}{l}\text { Cnidaria/ } \\
\text { Hydrozoa }\end{array}$ & 14 & $\begin{array}{c}5 \\
(36 \%)\end{array}$ & $\begin{array}{c}9 \\
(64 \%)\end{array}$ & $\begin{array}{c}8 \\
(58 \%)\end{array}$ & $\begin{array}{c}1 \\
(7 \%)\end{array}$ & $\begin{array}{c}2 \\
(14 \%)\end{array}$ & 0 & $\begin{array}{c}1 \\
(7 \%)\end{array}$ & $\begin{array}{c}1 \\
(7 \%)\end{array}$ & $\begin{array}{c}1 \\
(7 \%)\end{array}$ \\
\hline $\begin{array}{l}\text { Cnidaria/ } \\
\text { Octocorallia }\end{array}$ & 33 & $\begin{array}{c}2 \\
(6 \%)\end{array}$ & $\begin{array}{c}4-9 \\
(12-27 \%)\end{array}$ & $\begin{array}{c}9 \\
(82 \%)\end{array}$ & 0 & 0 & $\begin{array}{c}1 \\
(9 \%)\end{array}$ & $\begin{array}{c}1 \\
(9 \%)\end{array}$ & 0 & 0 \\
\hline $\begin{array}{l}\text { Cnidaria/ } \\
\text { Other }\end{array}$ & 3 & $\begin{array}{c}3 \\
(100 \%)\end{array}$ & 0 & 0 & 0 & 0 & 0 & 0 & 0 & $\begin{array}{c}3 \\
(100 \%)\end{array}$ \\
\hline Annelida & 29 & $\begin{array}{c}7 \\
(24 \%)\end{array}$ & $\begin{array}{c}0-8 \\
(0-28 \%)\end{array}$ & $\begin{array}{c}8 \\
(53 \%)\end{array}$ & 0 & 0 & $\begin{array}{c}1 \\
(7 \%)\end{array}$ & $\begin{array}{c}5 \\
(33 \%)\end{array}$ & 0 & $\begin{array}{c}1 \\
(7 \%)\end{array}$ \\
\hline Brachiopoda & 1 & $\begin{array}{c}1 \\
(100 \%)\end{array}$ & 0 & 0 & $\begin{array}{c}1 \\
(100 \%)\end{array}$ & 0 & 0 & 0 & 0 & 0 \\
\hline Bryozoa & 14 & $\begin{array}{c}4 \\
(29 \%)\end{array}$ & $\begin{array}{c}6-8 \\
(43-57 \%)\end{array}$ & $\begin{array}{c}8 \\
(67 \%)\end{array}$ & $\begin{array}{c}1 \\
(8 \%)\end{array}$ & $\begin{array}{c}2 \\
(17 \%)\end{array}$ & 0 & 0 & $\begin{array}{c}1 \\
(8 \%)\end{array}$ & 0 \\
\hline Mollusca & 10 & $\begin{array}{c}4 \\
(40 \%)\end{array}$ & $\begin{array}{c}3 \\
(30 \%)\end{array}$ & $\begin{array}{c}1 \\
(14 \%)\end{array}$ & $\begin{array}{c}3 \\
(44 \%)\end{array}$ & $\begin{array}{c}1 \\
(14 \%)\end{array}$ & 0 & $\begin{array}{c}1 \\
(14 \%)\end{array}$ & $\begin{array}{c}1 \\
(14 \%)\end{array}$ & 0 \\
\hline $\begin{array}{c}\text { Crustacea/ } \\
\text { Decapoda }\end{array}$ & 37 & $\begin{array}{c}13 \\
(35 \%)\end{array}$ & $\begin{array}{c}13-23 \\
(35-62 \%)\end{array}$ & $\begin{array}{c}18 \\
(50 \%)\end{array}$ & $\begin{array}{c}12 \\
(34 \%)\end{array}$ & $\begin{array}{c}3 \\
(8 \%)\end{array}$ & 0 & 0 & 0 & $\begin{array}{c}3 \\
(8 \%)\end{array}$ \\
\hline $\begin{array}{l}\text { Crustacea/ } \\
\text { Other }\end{array}$ & 32 & $\begin{array}{c}2 \\
(6 \%)\end{array}$ & $\begin{array}{c}22-28 \\
(69-88 \%)\end{array}$ & $\begin{array}{c}15 \\
(50 \%)\end{array}$ & $\begin{array}{c}12 \\
(40 \%)\end{array}$ & 0 & $\begin{array}{c}2 \\
(7 \%)\end{array}$ & 0 & $\begin{array}{c}1 \\
(3 \%)\end{array}$ & 0 \\
\hline $\begin{array}{c}\text { Echinodermata } \\
\text { Asteroidea }\end{array}$ & a/ 22 & $\begin{array}{c}7 \\
(32 \%)\end{array}$ & $\begin{array}{c}1-2 \\
(4-9 \%)\end{array}$ & $\begin{array}{c}2 \\
(22 \%)\end{array}$ & $\begin{array}{c}2 \\
(22 \%)\end{array}$ & $\begin{array}{c}2 \\
(22 \%)\end{array}$ & $\begin{array}{c}1 \\
(11 \%)\end{array}$ & $\begin{array}{c}1 \\
(11 \%)\end{array}$ & 0 & $\begin{array}{c}1 \\
(12 \%)\end{array}$ \\
\hline $\begin{array}{c}\text { Echinodermata } \\
\text { Ophiuroidea }\end{array}$ & a/ 36 & $\begin{array}{c}23 \\
(64 \%)\end{array}$ & $\begin{array}{c}3-11 \\
(8-31 \%)\end{array}$ & $\begin{array}{c}10 \\
(29 \%)\end{array}$ & $\begin{array}{c}2 \\
(6 \%)\end{array}$ & $\begin{array}{c}3 \\
(9 \%)\end{array}$ & $\begin{array}{c}4 \\
(12 \%)\end{array}$ & $\begin{array}{c}1 \\
(3 \%)\end{array}$ & 0 & $\begin{array}{c}14 \\
(21 \%)\end{array}$ \\
\hline $\begin{array}{l}\text { Echinodermata } \\
\text { Other }\end{array}$ & a/ 11 & $\begin{array}{c}4 \\
(36 \%)\end{array}$ & $\begin{array}{c}2-5 \\
(18-45 \%)\end{array}$ & $\begin{array}{c}5 \\
(55 \%)\end{array}$ & 0 & 0 & $\begin{array}{c}1 \\
(11 \%)\end{array}$ & 0 & $\begin{array}{c}1 \\
(11 \%)\end{array}$ & $\begin{array}{c}2 \\
(23 \%)\end{array}$ \\
\hline Total & 242 & $\begin{array}{c}75 \\
(31 \%)\end{array}$ & $\begin{array}{c}63-106 \\
(26-44 \%)\end{array}$ & $\begin{array}{c}84 \\
(35 \%)\end{array}$ & $\begin{array}{c}34 \\
(14 \%)\end{array}$ & $\begin{array}{c}13 \\
(5 \%)\end{array}$ & $\begin{array}{c}7 \\
(3 \%)\end{array}$ & $\begin{array}{c}10 \\
(4 \%)\end{array}$ & $\begin{array}{c}5 \\
(2 \%)\end{array}$ & $\begin{array}{c}25 \\
(10 \%)\end{array}$ \\
\hline
\end{tabular}




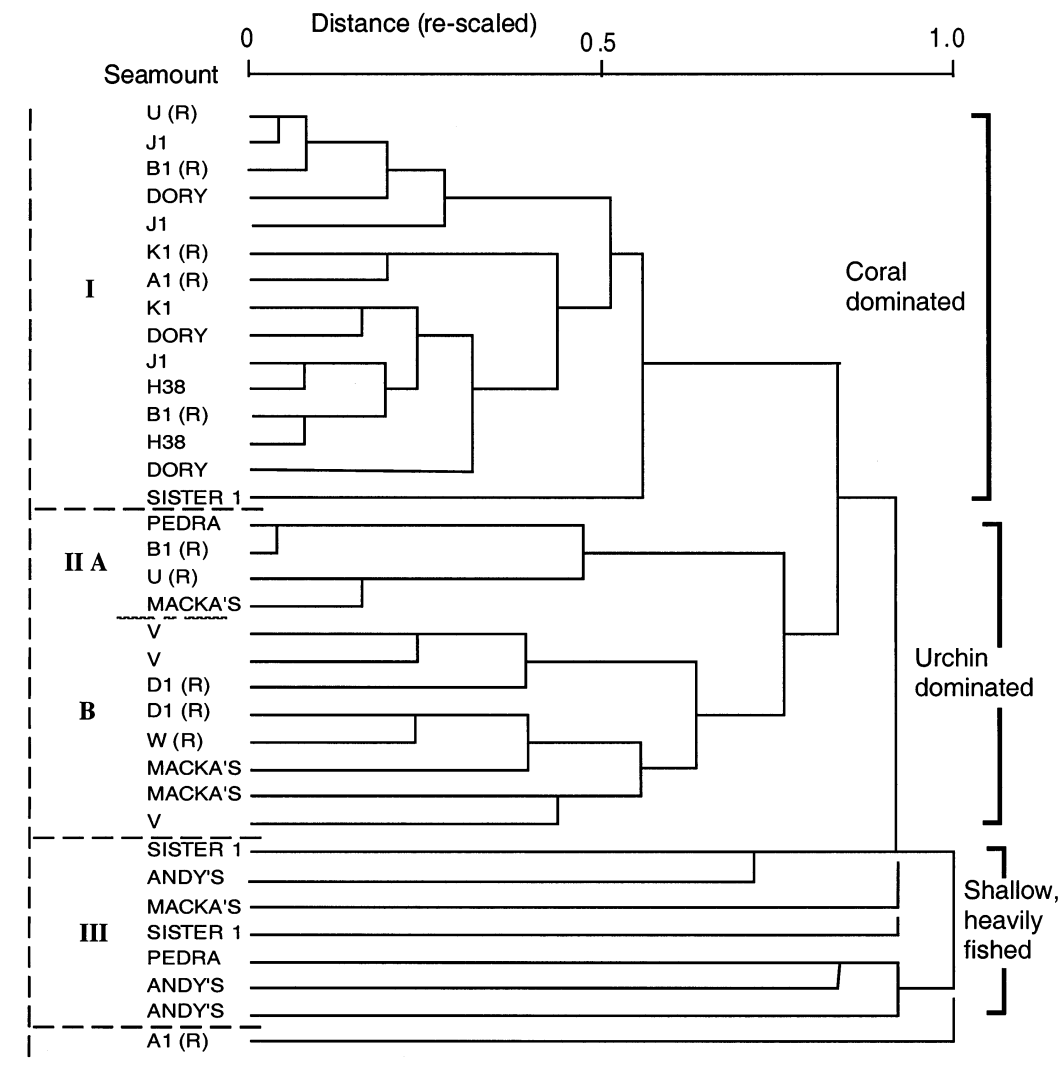

Fig. 5. Dendrogram based on cluster analysis of seamount dredge samples. Linkages indicate distance between samples based on Bray-Curtis index based on raw abundance data. Site locations are shown in Fig. 1. R: within protected area

tained a diverse assemblage, including Solenosmilia variabilis, and was associated with this cluster (Fig. 5), which further suggests that such seamounts supported this community prior to fishing.

Differences observed on the photographic transects between the summit, slope and base of the seamounts were not detected among these habitats in the dredge samples, possibly due to imprecision in placement of the dredge samples.

The urchin-dominated cluster had 2 sub-groups. The first (IIA in Fig. 5) consisted of several sites where the samples were small (mean sample weight: $1.25 \mathrm{~kg}$ ) and contained little except for sea urchins. Only 1 species was found only at these sites: a galatheid crab, Munida n. sp. 4, which is also known from the continental slope of southeast Australia.

The second subgroup (IIB in Fig. 5) consisted of all sites from the deepest seamounts, as well as 2 samples from Macca's, a shallow, heavily fished seamount. These sites had a predominance of sea urchins, a lack of live Solenosmilia variabilis and a variety of other invertebrates. Some species were most abundant at these sites, but all species also occurred at coral-dominated sites. This is probably because these sites typically con- tained large quantities of dead $S$. variabilis that the fauna could use as substrate or shelter. Several species of crustaceans and ophiuroids most characteristic of these sites were new to science and appear to be seamount endemics, e.g. Ophiomitrella sp. 1 and Ophiacantha sp. 1 (Table 5).

Several of the shallowest and most heavily fished sites from Andy's, Pedra, Sister 1 and Macca's were loosely associated with each other and little related to other sites, so they are grouped together in a tentative third cluster (Fig. 5). They were not dominated by either corals or urchins, but contained several species that were not common elsewhere (Table 5). However, these species were either found also on deeper seamounts (e.g. Michelopagurus n. sp.) or are known from the continental slope (e.g. Propagurus deprofundis, Lipkius holthuisi, Uroptychus australis). We found no species that occurred only on the shallow seamounts, which suggests that the fauna has affinities with both the surrounding slope and deeper seamounts and is not distinct in its own right. This cluster was not robust and tended to fragment depending on cluster method, although the sites continued to display little relationship to other sites.

Samples from Pedra and Sister 1 generally had no live colonial coral, Solenosmilia variabilis, but all had filter-feeding groups indicative of a coralline environment (e.g. gorgonians, bryozoans, solitary corals). However, as noted above, samples were significantly

Table 4. Means (standard deviations) of sample characteristics from sites identified by cluster analysis as dominated by corals (Cluster I), sea urchins (Cluster II) and shallow, heavily fished sites (Cluster III). (Cluster analysis in Fig. 5)

\begin{tabular}{|lrrc|}
\hline & Coral & Sea urchin & Heavily fished \\
\hline No. of sites & 15 & 12 & 8 \\
Mean depth (m) & 1213 & $1522^{\mathrm{a}}$ & 872 \\
Living biomass/ & 7.2 & 1.7 & 1.0 \\
sample (kg) & $(5.5)$ & $(1.9)$ & $(0.9)$ \\
Urchin biomass/ & 0.31 & 0.86 & 0.01 \\
sample (kg) & $(0.28)$ & $(0.95)$ & $(0.01)$ \\
No. of species/ & 20.9 & 14.3 & 10.8 \\
sample & $(3.6)$ & $(5.4)$ & $(6.6)$ \\
aExcluding Macca's & & \\
\hline
\end{tabular}


Table 5. Dominant species associated with cluster groups defined in Fig. 5. Depth, position and fishing effort of the seamounts are given in Table 1; seamount locations are shown in Fig. 1. (R) indicates site is within protected area. $\mathrm{x}$ : present at the sampling site

\begin{tabular}{|c|c|c|c|c|}
\hline Species & Group 1 & Group 2A & Group 2B & Group 3 \\
\hline & UJBDJKAKDJ B DS & PBUM & VVDDWMMV & SAMSPA \\
\hline & 1101111013130i & e1 a & 11 aa & inaien \\
\hline & $R \quad r \quad r 88 r s$ & $\mathrm{~d} R \mathrm{C}$ & $\mathrm{RCC}$ & sdcsdd \\
\hline & Ry RRRy $R$ yt & $r R \mathrm{~K}$ & $\mathrm{RR} C \mathrm{C}$ & tyctry \\
\hline & e & a a & aa & esaeas \\
\hline & r & $\mathrm{s}$ & ss & $r$ sr \\
\hline & 1 & & & 11 \\
\hline 1 Solenosmilia variabilis & 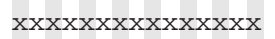 & & $x$ & \\
\hline 2 Solitary corals & 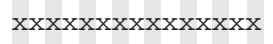 & $\mathrm{x}$ & $\mathrm{xx} x \mathrm{xx} \times \mathrm{x}$ & $x x \quad x$ \\
\hline 3 Stylaster eguchii & $x \times x x x x x x x \quad x \quad x$ & $\mathrm{x}$ & $x x \times x \quad x$ & $x x \quad x$ \\
\hline 4 Antipatharia & $\operatorname{xxx} x \mathrm{x} x \mathrm{x} \quad \mathrm{x} \quad \mathrm{x}$ & $\mathrm{x}$ & $x x x \quad x$ & $x x \quad x$ \\
\hline 5 Brachiopoda & 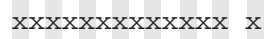 & & $\mathrm{xxx} \mathrm{xxx}$ & $\mathrm{x} \quad \mathrm{x}$ \\
\hline 6 Delectopecten fosterianum & 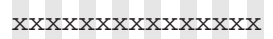 & & $\mathrm{xx}$ & $x$ \\
\hline 7 Trichopeltarion n. sp. & $\mathrm{xxxxx} \quad \mathrm{xxxxxxxxx}$ & & $x x \times x \quad x$ & $x \mathrm{x}$ \\
\hline 8 Munida n. sp. 1 & 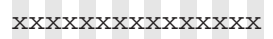 & $\mathrm{x} x \mathrm{x}$ & $\mathrm{xx} \quad \mathrm{x} x \mathrm{x}$ & $x x \quad x$ \\
\hline 9 Munida n. sp. 2 & $x x \quad x x x x \quad x x x \quad x$ & & $\mathrm{xx} \quad \mathrm{x}$ & $x$ \\
\hline 10 Munida n. sp. 3 & $\begin{array}{llll}x & x x & x & x\end{array}$ & & $\mathrm{xx} x$ & \\
\hline 11 Paguridae n. gen. & $x x x \quad x \quad x \quad x \quad x$ & $\mathrm{x}$ & $\mathrm{x}$ & $x$ \\
\hline 12 Eualus sp. & $x \quad x x x \quad x x \quad x \quad x \quad x$ & & $\mathrm{xx}$ & $x$ \\
\hline 13 Ophiura n. sp. & $x \quad x \quad x x x x \quad x x x x \quad x$ & $x$ & $\mathrm{xxxx}$ & \\
\hline 14 Ophiacantha rosea & 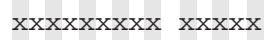 & & $x x x x x \quad x x$ & \\
\hline 15 Ophiacantha vivipara & 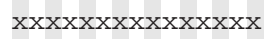 & & $\mathrm{xx}$ & \\
\hline 16 Ophiacantha denvispina & $x \times x x x \quad x x x x x x x x x$ & & $\mathrm{x} x \mathrm{xx}$ & $x$ \\
\hline 17 Ophiacantha spectabilis & $\begin{array}{llllll}x x & x & x & x & x\end{array}$ & & $x x$ & \\
\hline 18 Ophiacantha yaldwyni & $x \times x \quad x$ & & $\mathrm{xxx}$ & $x$ \\
\hline 19 Ophiacantha vepractica & $x \quad x \quad x \quad x x x$ & & $\mathrm{xx}$ & \\
\hline 20 Ophiacantha n. sp. 2 & $\mathrm{x} \quad \mathrm{x} x \mathrm{x}$ & & $x$ & \\
\hline 21 Munida n. sp. 4 & & $x \mathrm{x}$ & & \\
\hline 22 Anthomastus sp. & $x \times x \quad x$ & $x \mathrm{x}$ & $\mathrm{xxx}$ & \\
\hline 23 Ophiolimna sp. & $x \quad x x \quad x$ & $\mathrm{x}$ & $\mathrm{xxxx}$ & \\
\hline 24 Ophiomitrella sp. 1 & $\mathrm{xx} x \mathrm{x}$ & & $\operatorname{xxxx}$ & \\
\hline 25 Ophiacantha sp. 1 & $\mathrm{xx} \times \mathrm{x}$ & & $\mathrm{xxxx}$ & $x$ \\
\hline 26 Ophiocten hastatum & $\mathrm{x}$ & & $\mathrm{xxx}$ & \\
\hline 27 Uroptychus australis & $x$ & & $\mathrm{xx}$ & $x \times$ \\
\hline 28 Lipkius holthuisi & $\mathrm{x}$ & $\mathrm{x}$ & $x \mathrm{xx}$ & $\mathrm{xx} x \mathrm{xx}$ \\
\hline 29 Propagurus deprofundis & & & & $x \quad x$ \\
\hline 30 Michelopagurus n. sp. & $\mathrm{x} x$ & & $\mathrm{x}$ & $x \quad x x$ \\
\hline
\end{tabular}

smaller $(14 \%$ of the mean weight of samples from coral-dominated sites) and contained significantly fewer species groups ( $~ 50 \%$ reduction in species numbers per sample) (Table 4$)$. The photographic transects indicated that the shallow, heavily fished seamounts, such as Main Pedra and Sister 1, were often dominated by soft corals (e.g. gorgonians) (10 to 100/frame). Although present on the deeper seamounts in the protected area, they were far less common (typically 0 to $1 /$ frame).

\section{Species associations}

Cluster analysis of the species' distributions carried out on presence/absence data (not shown) indicated that 1 cluster (Cluster 1) contained most of the species, including all the corals and virtually all ophiuroids, a notably diverse group. Core members of Cluster 1 were widely distributed, but occurred predominantly

Table 6. Comparison of mean sample weight and no. of species per sample $\pm 95 \%$ confidence limits from the top and slopes of heavily fished and lightly fished seamounts (inside and outside the protected area [PA]). Urchin-dominated seamounts have been excluded

\begin{tabular}{|lccc|}
\hline & $\begin{array}{c}\text { Heavily fished } \\
(\mathrm{n}=11)\end{array}$ & $\begin{array}{c}\text { Lightly fished } \\
(\mathrm{n}=11)\end{array}$ & $\begin{array}{c}\text { PA } \\
(\mathrm{n}=12)\end{array}$ \\
\hline Biomass $(\mathrm{kg})$ & 1.1 & 7.0 & 6.1 \\
& \pm 3.4 & \pm 5.8 & \pm 3.8 \\
No. of species & 8.7 & 20.1 & 22.2 \\
& \pm 6.3 & \pm 3.6 & \pm 4.6 \\
\hline
\end{tabular}


on lightly fished seamounts (Table 7). Two small clusters (Clusters 2 and 3) had their center of distribution primarily on the heavily fished, shallow seamounts. They consisted predominantly of decapod crustaceans that are found also on the continental slope off southeastern Australia (Leontocaris amplectipes and $L$. yarramundi, Lipkius holthuisi, Uroptychus sp., Propagurus deprofundis, and Merhippolyte chacei), although several species (Michelopagurus sp. and Spongicaris sp.) appear to be new. A small sub-group of Cluster 1 (Cluster 1.5), consisting of several decapod and ophiuroid species, occurred predominantly on several of the deeper seamounts (Table 7). Non-metric dimensional scaling analysis based on presenceabsence data and cluster analysis carried out on the raw abundance data (not shown) indicated a similar distribution of species groups.

\section{DISCUSSION}

Documented concerns about the environmental impacts of trawling date back to the mid-1300s (de Groot 1984), but the scientific literature on this subject has increased markedly in the past decade (e.g. Hutchings 1990, Jones 1992, Dayton et al. 1995, Thrush et al. 1995, Auster et al. 1996, Collie et al. 1997, Jennings \& Kaiser 1998). These studies have demonstrated a variety of trawling impacts: direct impacts on the benthic fauna and substrate, and secondary impacts, particularly on fishes, arising from reduced cover and habitat complexity. However, most of these studies have focussed on soft - or at least, non-reefal - substrates, where trawling is generally carried out.

The impact of trawling on complex seamount reefs appears to be dramatic, with the coral substrate and

Table 7. Proportion of species from clusters based on presence/absence data occurring at each sample site. ${ }^{*}$ : proportion of species greater than the mean; ${ }^{* *}$ : proportion of species greater than twice the mean. Stations are listed from shallowest to deepest. T: top; S: Slope; B: base

\begin{tabular}{|c|c|c|c|c|c|}
\hline Station & Cluster 1 & Cluster 1.5 & Cluster 2 & Cluster 3 & Mean \\
\hline Andy (T) & $0.27^{*}$ & 0.00 & 0.00 & $0.40^{*}$ & 0.22 \\
\hline Andy (S) & 0.39 & 0.00 & 0.40 & $1.00^{* *}$ & 0.40 \\
\hline Andy (B) & $0.68^{*}$ & 0.00 & 0.60 & $0.80^{*}$ & 0.60 \\
\hline Macca (T) & $0.39^{*}$ & 0.00 & $0.60^{*}$ & $0.60^{*}$ & 0.38 \\
\hline Macca (T2) & $0.27^{*}$ & 0.00 & 0.00 & 0.00 & 0.19 \\
\hline Macca (S) & $0.39^{*}$ & 0.00 & $0.60^{*}$ & $0.60^{*}$ & 0.38 \\
\hline Macca (B) & $0.10^{*}$ & 0.00 & 0.00 & $0.20^{* *}$ & 0.09 \\
\hline Pedra $(\mathrm{T})$ & 0.20 & 0.00 & 0.00 & $0.80^{* *}$ & 0.21 \\
\hline Pedra (B) & $0.20^{*}$ & 0.00 & 0.00 & $0.40^{* *}$ & 0.17 \\
\hline Sister (T) & 0.10 & 0.00 & 0.00 & $0.40^{* *}$ & 0.10 \\
\hline Sister (S) & $0.20^{*}$ & 0.00 & $0.20^{*}$ & $0.40^{* *}$ & 0.19 \\
\hline Sister (B) & $0.93^{*}$ & 0.43 & 0.60 & 0.40 & 0.79 \\
\hline Dory (T) & $0.71^{*}$ & 0.00 & 0.00 & 0.20 & 0.52 \\
\hline Dory (S) & $0.37^{*}$ & 0.00 & 0.00 & 0.00 & 0.26 \\
\hline Dory (B) & $0.59^{*}$ & 0.00 & 0.00 & 0.00 & 0.41 \\
\hline $\mathrm{U}(\mathrm{T})$ & $0.90^{*}$ & 0.14 & 0.20 & 0.20 & 0.69 \\
\hline $\mathrm{U}(\mathrm{S})$ & $0.24^{*}$ & 0.14 & 0.00 & 0.00 & 0.19 \\
\hline H38 (T) & $0.66^{*}$ & 0.57 & $0.60^{*}$ & 0.00 & 0.59 \\
\hline H38 (SB) & $0.71^{*}$ & 0.43 & 0.00 & 0.00 & 0.55 \\
\hline $\mathrm{J} 1(\mathrm{~T})$ & $0.46^{*}$ & 0.00 & 0.00 & 0.60 & 0.38 \\
\hline J1 (S) & $0.90^{*}$ & 0.57 & $0.80^{*}$ & 0.00 & 0.78 \\
\hline J1 (B) & $0.73^{*}$ & 0.29 & 0.00 & 0.40 & 0.59 \\
\hline $\mathrm{A} 1(\mathrm{~T})$ & $0.54^{*}$ & $0.71^{*}$ & 0.00 & 0.00 & 0.47 \\
\hline A1 (S) & $0.07^{*}$ & 0.00 & 0.00 & 0.00 & 0.05 \\
\hline $\mathrm{B} 1$ (T) & $0.83^{*}$ & 0.00 & 0.40 & 0.00 & 0.62 \\
\hline B1 (S) & $0.63^{*}$ & $0.86^{*}$ & 0.00 & 0.20 & 0.57 \\
\hline B1 (B) & $0.17^{*}$ & 0.00 & 0.00 & 0.00 & 0.12 \\
\hline K1 (S) & $0.59^{*}$ & 0.14 & 0.00 & 0.00 & 0.43 \\
\hline K1 (S2) & $0.88^{*}$ & 0.14 & 0.00 & 0.20 & 0.66 \\
\hline $\mathrm{V}(\mathrm{T})$ & $0.76^{*}$ & $1.00^{*}$ & 0.00 & 0.00 & 0.66 \\
\hline $\mathrm{V}(\mathrm{S})$ & $0.88^{*}$ & $1.00^{*}$ & 0.00 & 0.20 & 0.76 \\
\hline $\mathrm{V}$ (B) & $0.61^{*}$ & $0.71^{*}$ & 0.00 & 0.00 & 0.52 \\
\hline $\mathrm{D} 1(\mathrm{~T})$ & $0.44^{*}$ & 0.29 & 0.00 & 0.20 & 0.36 \\
\hline D1 (B) & $0.46^{*}$ & 0.14 & 0.00 & 0.00 & 0.34 \\
\hline $\mathrm{W}(\mathrm{T})$ & $0.15^{*}$ & 0.00 & 0.00 & 0.00 & 0.10 \\
\hline Mean & 0.50 & 0.22 & 0.14 & 0.23 & 0.41 \\
\hline
\end{tabular}


associated community largely removed from the most heavily fished seamounts. The virtually complete loss of this community from the shallow heavily fished seamounts is not surprising, given the limited extent of the seamounts under study - most are on the order of $2 \mathrm{~km}$ in diameter at the base and 300 to $600 \mathrm{~m}$ high and the hundreds to thousands of trawls carried out on each. This devastating impact is consistent with other studies of the impact of trawling on reefal or other benthic communities dominated by megabenthos (Bradstock \& Gordon 1983, Sainsbury 1988).

The life history of most seamount species is unknown, but those studies that have been carried out indicate that they are generally long-lived, slow-growing and easily depleted (Vacelet et al. 1992, Grigg 1993, Rogers 1994). The distribution of the benthic seamount fauna of the Southwest Pacific is also notably localized - more so than either the soft-bottom slope or hydrothermal vent faunas (Richer de Forges et al. 2000) - so conservation of this fauna must be considered exceptionally vulnerable to widespread trawling.

Although the influence of depth and trawling cannot be unambiguously distinguished due to the lack of baseline data and confounding of these variables, there can be little doubt of the massive impact of trawling on the seamount benthos. The substrate of heavily fished seamounts in the area now consists predominantly of either bare rock or coral rubble and sand, features not seen on any seamount that was lightly fished or unfished. The abundance and species richness of the benthic fauna on heavily fished seamounts was also markedly reduced. This apparent impact of fishing on the seamount benthos is consistent with anecdotal information from fishers, which indicates that during the early period of the fishery, trawl catches on now-heavily fished seamounts included significant quantities of live coral and coral aggregate, which has subsequently disappeared.

In 1999, the Australian government proclaimed the protected area shown in Fig. 1, initially designated on an interim basis in 1995, to be a permanent reserve. This area of $370 \mathrm{~km}^{2}$ contains 12 seamounts that peak at depths between 1300 and $>1700 \mathrm{~m}$. The protected area was declared primarily to protect the seamount fauna from the impacts of orange roughy trawling. However, given that the protected area does not include any shallow seamounts, is the seamount fauna of the region adequately conserved?

Our community analyses indicated that most species were widely distributed over the depth range sampled, but decreased in abundance at the shallowest and deepest seamounts sampled. The decline at deeper depths appeared to follow from an overall decline in benthic biomass and species richness on the deepest seamounts. The cause of the relatively high proportion of dead Solenosmilia variabilis on the deeper sea-mounts is not known, although it could be due to temporal changes in growth conditions, predation or disease, all of which are unstudied in this environment. Several species were most abundant at these sites, suggesting a possible shift in community composition.

At the shallow, heavily fished seamounts, most of the shift in community composition could be ascribed to the impacts of trawling, which effectively removed the dominant colonial coral, Solenosmilia variabilis, and its associated fauna. Recovery of a sample from the base of the heavily fished hill, Sister, with strong affinities to the fauna on deeper unfished seamounts, lends support to the hypothesis that the pre-fishery seamount fauna was, for the most part, broadly distributed over mid-slope depths ( 650 to $1400 \mathrm{~m}$ ). The higher abundance of gorgonians on the shallower, heavily fished seamounts, noted in the photographic transects, could be due either to a preference for shallower depths or an ability to rapidly colonize disturbed grounds and to withstand trawl disturbance through greater pliability. The latter possibility is supported by 2 rock slabs obtained on the cruise that contained gorgonians on one surface and broken coral bases underneath, indicating that the rock had been overturned by trawling and newly colonized by gorgonians. Otherwise, the several species whose center of distribution was on these shallower seamounts were virtually all known from the slope fauna (Poore et al. 1994). This appears to indicate that the fauna unique to the seamounts is adequately represented within the depth range of seamounts found within the protected area. However, given the highly disturbed and depauperate fauna presently observed on these shallower seamounts and the generally high incidence on seamounts of rare species with highly restricted distributions (Richer de Forges et al. 2000), we cannot rule out the possibility that seamount-restricted species with shallow depth affinities may have been eliminated by trawling, at least regionally.

We observed no secondary ecological impacts to the region's deepwater fisheries arising from the loss of coral habitat. No juveniles of orange roughy or oreosomatid fishes were obtained from the reef habitat, and the dominant benthopelagic fishes feed mostly on prey within the water column (Clark et al. 1989, Bulman \& Koslow 1992). However, the removal of the reef habitat formed by Solenosmilia variabilis clearly may affect the several fishes and numerous invertebrate species associated with the coral substrate, many of which appear to be endemic to the region. In general, present observations of seamount reefs are too limited to form definitive conclusions regarding their ecological role in the deep sea. 
Acknowledgements. Financial support for this research was received from the Fisheries Research Development Corporation and Environment Australia. We thank K. Sainsbury, P. Hone, P. Taylor, H. Sullivan, S. Blaber, and T. Smith for their comments. M. Lewis drafted the figures. N. Bax provided the data on fishing effort and S. Rainer assisted with several analyses. We are grateful to all participants on Cruise SS9701 and the captain, fishing master, and crew of 'Southern Surveyor'. We thank the following, who identified specimens from the collections: H. Clark and D. McKnight (asteroids and echinoids), S. Hart, J. Taylor and C. Tudge (decapods), P. Allderslade (octocorallia), J. Watson (hydroids), A. Murray and K. Attwood (polychaetes), D. Gordon (Bryozoa), P. McLaughlin (pagurids), P. Davie (atelecyclids), N. Améziane (crinoids), C. Mah (brisingid asteroids), M. O'Loughlin (holothurians), T. Stranks (cephalopods), S. Boyd and B. Marshall (bivalves), D. Jones (barnacles), and S. Keable and R. Johnson (isopods, ostracods and amphipods).

\section{LITERATURE CITED}

AGSO (1995) Bathymetric map of fishing grounds south of Tasmania with names of fishing grounds and indication of rough sea bed. Australian Geological Survey Organisation, Canberra (Special Map, scale 1:100 000)

Auster PJ, Malatesta RJ, Langton RW, Watling L, Valentine PC, Donaldson CL, Langton EW, Shepard AN, Babb IG (1996) The impacts of mobile fishing gear on seafloor habitats in the Gulf of Maine (Northwest Atlantic): implications for conservation of fish populations. Rev Fish Sci 4:185-202

Boehlert GW, Sasaki T (1988) Pelagic biogeography of the armorhead, Pseudopentaceros wheeleri, and recruitment to isolated seamounts in the North Pacific Ocean. Fish Bull 86:453-465

Bradstock M, Gordon DP (1983) Coral-like bryozoan growths in Tasman Bay, and their protection to conserve commercial fish stocks. NZ J Mar Freshw Res 17:159-163

Bulman CM, Koslow JA (1992) Diet and food consumption of a deep-sea fish, orange roughy Hoplostethus atlanticus (Pisces: Trachichthyidae), off southeastern Australia. Mar Ecol Prog Ser 82:115-129

Chiu TS, Markle DF (1990) Muraenolepididae. In: Gon O, Heemstra PC (eds) Fishes of the Southern Ocean. JLB Smith Institute of Ichthyology, Grahamstown, p 179-182

Clark MR (1999) Fisheries for orange roughy (Hoplostethus atlanticus) on seamounts in New Zealand. Oceanol Acta 22:593-602

Clark MR, King KJ, McMillan PJ (1989) The food and feeding relationships of black oreo, Allocyttus niger, smooth oreo, Pseudocyttus maculatus, and eight other fish species from the continental slope of the south-west Catham Rise, New Zealand. J Fish Biol 35:465-484

Collie JS, Escanero GA, Valentine PC (1997) Effects of bottom fishing on the benthic megafauna of Georges Bank. Mar Ecol Prog Ser 155:159-172

Dayton PK, Thrush SF, Agardy MT, Hofman RJ (1995) Environmental effects of marine fishing. Aquat Conserv Mar Freshw Ecosyst 5:205-232

de Groot SJ (1984) The impact of bottom trawling on benthic fauna of the North Sea. Ocean Manag 9:177-190

Genin A, Dayton PK, Lonsdale PF, Spiess FN (1986) Corals on seamounts provide evidence of current acceleration over deep sea topography. Nature 322:59-61

Genin A, Haury L, Greenblatt P (1988) Interactions of migrating zooplankton with shallow topography: predation by rockfishes and intensification of patchiness. Deep-Sea Res
35:151-175

Grigg RW (1993) Precious coral fisheries of Hawaii and the US Pacific islands. Mar Fish Rev 55:50-60

Grigg RW, Brown G (1991) Tasmanian gem corals. Aust Gemmologist May:399-404

Hill PJ, Exon NF, Koslow JA (1997) Multibeam sonar mapping of the sea bed off Tasmania: results for geology and fisheries. Third Australasian Hydrographic Symposium, Maritime Resource Development, Symposium papers, Spec Publ 38:9-19

Hutchings P (1990) Review of the effects of trawling on macrobenthic epifaunal communities. Aust J Mar Freshw Res 41:111-120

Jennings S, Kaiser MJ (1998) The effects of fishing on marine ecosystems. Adv Mar Biol 34:201-352

Jones JB (1992) Environmental impact of trawling on the seabed: a review. NZ J Mar Freshw Res 26:59-67

Koslow JA (1994) Assessment of conservation and management requirements for southern seamounts. Australian Nature Conservation Agency, Canberra (Report to Ocean Rescue 2000)

Koslow JA (1996) Energetic and life-history patterns of deepsea benthic, benthopelagic and seamount-associated fish. J Fish Biol 49(Suppl A):54-74

Koslow JA (1997) Seamounts and the ecology of deep-sea fisheries. Am Sci 85:168-176

Koslow JA, Gowlett-Holmes K (1998) The seamount fauna off southern Tasmania: benthic communities, their conservation and impacts of trawling. CSIRO Marine Research, Hobart (Report to the Fisheries Research Development Corporation and Environment Australia)

Koslow JA, Bulman CM, Lyle JM (1994) The mid-slope demersal fish community off southeastern Australia. Deep-Sea Res 41:113-141

Koslow JA, Boehlert GW, Gordon JDM, Haedrich RL, Lorance P, Parin N, (2000) The impact of fishing on continental slope and deep-sea ecosystems. ICES J Mar Sci 57:548-557

Legendre L, Legendre P (1983) Numerical ecology. Elsevier Science B.V., Amsterdam

Lewis M (1999) CSIRO-SEBS (Seamount epibenthic sampler), a new epibenthic sled for sampling seamounts and other rough terrain. Deep-Sea Res 46:1101-1107

Norusis MJ (1994) SPSS Professional Statistics 6.1. SPSS, Chicago

Paxton JR, Hoese DF, Allen GR, Hanley JE (1989) Zoological catalogue of Australia, Vol 7. Pisces-Petromyzontidae to Carangidae. Australian Government Publishing Service, Canberra

Poore GCB, Just J, Cohen BF (1994) Composition and diversity of Crustacea Isopoda of the southeastern Australian continental slope. Deep-Sea Res 41:677-693

Probert PK, McKnight DG, Grove SL (1997) Benthic invertebrate bycatch from a deep-water trawl fishery, Chatham Rise, New Zealand. Aquat Conserv Mar Freshw Ecosyst 7: $27-40$

Richer de Forges B (1998) La diversité du benthos marin de Nouvelle-Caledonie: de l'espèce a la notion de patrimonie. PhD thesis, Museum National d'Histoire Naturelle, Paris

Richer de Forges B, Koslow JA, Poore GCB (2000) Diversity and endemism of the benthic seamount macrofauna in the southwest Pacific. Nature 405:944-947

Roden GI (1986) Aspects of oceanic flow and thermohaline structure in the vicinity of seamounts. In: Uchida RN, Hayasi S, Boehlert GW (eds) Environment and resources of seamounts in the North Pacific. NOAA Tech Rep NMFS $43: 3-12$ 
Rogers AD (1994) The biology of seamounts. Adv Mar Biol 30: 305-350

Sainsbury KJ (1988) The ecological basis of multispecies fisheries and management of a demersal fishery in tropical Australia. In: Gulland JA (ed) Fish population dynamics. J Wiley \& Sons, London, p 349-382

Thrush SF, Hewitt JE, Cummings VJ, Dayton PK (1995) The impact of habitat disturbance by scallop dredging on marine benthic communities: what can be predicted from the results of experiments? Mar Ecol Prog Ser 129:141-150

Editorial responsibility: Otto Kinne (Editor),

Oldendorf/Luhe, Germany
Tseitlin VB (1985) The energetics of fish populations inhabiting seamounts. Oceanology 25:237-239

Vacelet J, Cuif JP, Gautret P, Massot M, Richer de Forges B, Zibrowius H (1992) A colonial sphinctozoan sponge related to Triassic reef builders surviving in deep water off New Caledonia. C R Acad Sci Par Ser III 314:379-385

Wilson RR, Kaufmann RS (1987) Seamount biota and biogeography. In: Keating $\mathrm{BH}$, Fryer P, Batiza R, Boehlert, GW (eds) Seamounts, islands and atolls. American Geophysical Union, Washington, DC, p 319-334

Submitted: December 23, 1999; Accepted: August 9, 2000 Proofs received from author(s): March 15, 2001 